\title{
IMUNOSUPRESINIS GYDYMAS PO PLAUČIŲ TRANSPLANTACIJOS
}

\author{
EDITA GASIŪNIENE' ', VALDAS ŠARAUSKAS '², DOC. DR. BRIGITA ŠITKAUSKIENE' ' \\ 1 KMU PULMONOLOGIJOS IR IMUNOLOGIJOS KLINIKA \\ 2 KMU PATOLOGINĖS ANATOMIJOS KLINIKA
}

\begin{abstract}
Reikšminiai žodžiai: indukcinė imunosupresija, palaikomoji imunosupresija, atmetimo reakcijos, plaučių transplantacija. Santrauka. Tarptautinès širdies ir plaučių transplantacijos asociacijos duomenimis, 2000-2006 metais indukcinè imunosupresija buvo taikyta 54 proc. pacienty po plaučiu transplantacijos. Indukcinei imunosupresijai naudoti šie imunosupresiniai vaistai: polikloniniai antikūnai, IL-2 antagonistai, monokloniniai antikūnai. Palaikomajai imunosupresijai skiriamas triju vaistu derinys, i kuri jeina kalcineurino inhibitorius, antiproliferacinis vaistas ir gliukokortikosteroidas. Gydant persistuojančią ūminę atmetimo reakciją pirmiausia ciklosporinas A pakeičiamas takrolimusu. Gydant lètinę atmetimo reakciją modifikuojama palaikomoji imunosupresija, imunosupresinis gydymas papildomas kitų grupių vaistais, skiriama imuninę sistemą moduliuojanti terapija (limfmazgių švitinimas, fotoferezè).
\end{abstract}

Per pastaruosius 20 metų plaučiu transplantacija tapo gyvybę gelbstintis gydymas pacientams, sergantiems paskutinių stadijų plaučių ligomis. Jei transplantacija sėkminga, atsitaiso plaučių funkcija, labai pagerẻja šių sunkiai sergančiu pacientų gyvenimo kokybė. Deja, vèlyvieji plaučiuc transplantacijos rezultatai nèra tokie džiuginantys. Penkerių metų išgyvenamumas po plaučių transplantacijos siekia 50 proc. Dvi pagrindinès priežastys, lemiančios mirti po plaučių transplantacijos, - tai obliteracinis bronchiolitas, kuris, manoma, yra alotransplantato bronchų ar bronchiolių lètinio atmetimo išraiška, bei infekcija. Abi komplikacijos yra nepakankamos imunosupresijos ženklas, todèl norint pagerinti vèlyvuosius plaučių transplantacijos rezultatus labai svarbu optimizuoti imunosupresini gydymą.

Esminis dalykas, padejjęs pagerinti vẻlyvuosius plaučiu transplantacijos rezultatus, buvo ciklosporino A sukūrimas. Iki tol, plaučiu transplantacijos baigdavosi nesėkmingai, nes imunitetui slopinti vartotos didelès steroidu dozès kartu su azatioprinu - toks gydymas sukeldavo anastomozès problemas ir buvo nepakankamas kontroliuoti ūmines atmetimo reakcijas.

\section{INDUKCINĖ IMUNOSUPRESIJA}

Indukcinės imunosupresijos tikslas - išvengti ūminių atmetimo reakcijų per pirmąsias keletą savaičiu po plaučių transplantacijos, t. y. tada, kai jų dažnumas pats didžiausias
[1]. Tarptautinès širdies ir plaučių transplantacijos asociacijos duomenimis, 2000-2006 metais indukciné imunoterapija buvo taikyta 54 proc. pacientu, kuriems transplantuoti plaučiai. Indukcinei imunosupresijai buvo vartojami šie imunosupresiniai vaistai: polikloniniai antikūnai (ATG), IL-2 antagonistai (baziliksimabas, daklizumabas), o nuo 2003 metuc pradètasi vartoti monokloniniai antikūnai (alemtuzumabas). Imunosupresiniai vaistai, jų veikimo mechanizmai ir šalutinis poveikis pateikti 1 lentelèje.

Polikloniniai antitimocitiniai antikūnai. Antitimocitinis globulinas (ATG) - preparatas, gaunamas iš triušių arba arklių imunizuotų žmogaus užkrūčio liaukos ląstelėmis ar limfocitais. Vèliau atskiriamai bei išgryninami antikūnai prieš žmogaus ląsteles. Šie antikūnai „puola“ daugybę membranos antigenų, kai kurie iš jų būna išskirtinai ant T limfocitu (CD3, CD4, CD8), o kai kurių randama ant daugelio cirkuliuojančių ląstelių (adhezijos molekulès CD11b, CD18) [2]. Pradejus gydyti, greitai pasireiškia gili leukopenija, todèl reikia nuolat stebèti limfocituc koncentraciją kraujyje, o dèl to padidejja indukcinès imunoterapijos kaštai, bet taip pavyksta išvengti per didelès imunosupresijos bei hematologinių komplikacijų [3, 4].

Interleukino-2 receptoriu monokloniniai antagonistai (baziliksimabas, daklizumabas). Pagrindinis skirtumas tarp monokloninių bei polikloninių antikūnų yra tas, kad monokloniniai antikūnai prieš $\mathrm{IL}-2$ receptorius blokuoja tik suaktyvejjusias $\mathrm{T}$ ląsteles, o polikloniniai - ir suak- 
1 lentelè. IMUNOSUPRESINIAIVAISTAI, JŲ VEIKIMO MECHANIZMAS, ŠALUTINIS POVEIKIS

\begin{tabular}{|c|c|c|c|}
\hline Vaistų grupè & Vaisto pavadinimas & Veikimo mechanizmas & Šalutinis vaisto poveikis \\
\hline $\begin{array}{l}\text { Polikloniniai antikūnai } \\
\text { (antilimfocitų antikūniai) }\end{array}$ & ATG & $\begin{array}{l}\text { Fiksuoja antigenus ant limfoidinių } \\
\text { ląstelių; mažina cirkuliuojančių } \\
\text { limfocitų skaičių }\end{array}$ & $\begin{array}{l}\text { Citokinus atpalaiduojantis sindromas; } \\
\text { leukocitopenija, trombocitopenija }\end{array}$ \\
\hline \multirow[t]{2}{*}{$\begin{array}{l}\text { Monokloniniai antikūnai } \\
\text { (antilimfocitų antikūniai) }\end{array}$} & ОКТ3 & $\begin{array}{l}\text { Fiksuoja CD3, esančius ant T- } \\
\text { limfocitų; mažina cirkuliuojančių } \\
\text { limfocitų skaičių }\end{array}$ & $\begin{array}{l}\text { Citokinus atpalaiduojantis sindromas; } \\
\text { prokoaguliacinis poveikis }\end{array}$ \\
\hline & Alemtuzumabas & $\begin{array}{l}\text { Fiksuoja CD52 ant B ir T limfocitų } \\
\text { paviršiaus, mažina cirkuliuojančių } \\
\text { limfocitų skaičių }\end{array}$ & $\begin{array}{l}\text { Limfocitopenija, trombocitopenija, } \\
\text { hipotenzija }\end{array}$ \\
\hline \multirow[t]{2}{*}{ IL-2 receptorių antagonistai } & Daklizumabas & $\begin{array}{l}\text { Sujungia IL-2 receptoriu alfa grandi- } \\
\text { nę; blokuoja IL-2 sukeltą proliferaciją }\end{array}$ & $\begin{array}{l}\text { Dispepsijos reiškiniai, infekcinės } \\
\text { komplikacijos }\end{array}$ \\
\hline & Baziliksimabas & $\begin{array}{l}\text { Sujungia IL-2 receptorių alfa grandi- } \\
\text { nę; blokuoja IL-2 sukeltą proliferaciją }\end{array}$ & $\begin{array}{l}\text { Šlapimo takų bei kitos infekcijos, } \\
\text { hipertenzija, anemija }\end{array}$ \\
\hline \multirow[t]{2}{*}{ Kalcineurino inhibitoriai } & Ciklosporinas A & $\begin{array}{l}\text { Sujungia ciklofiliną, slopina kal- } \\
\text { cineuriną; slopina citokinų genų } \\
\text { transkripciją }\end{array}$ & $\begin{array}{l}\text { Nefrotoksiškumas, hipertenzija, hiper- } \\
\text { cholesterolemija, hipertrichozè, dantenų } \\
\text { hipertrofija }\end{array}$ \\
\hline & Takrolimas & $\begin{array}{l}\text { Sujungia FKBP-12; slopina kalcineuri- } \\
\text { ną; slopina citokinų genų transkripciją }\end{array}$ & $\begin{array}{l}\text { Nefrotoksiškumas, hipertenzija, cukrinis } \\
\text { diabetas, neurotoksiškumas, alopecija }\end{array}$ \\
\hline \multirow[t]{3}{*}{ Antiproliferaciniai vaistai } & Azatioprinas & $\begin{array}{l}\text { Slopina purinų biosintezę ir limfoci- } \\
\text { tụ proliferaciją }\end{array}$ & Leukocitopenija \\
\hline & $\begin{array}{l}\text { Mikofenolato } \\
\text { mofetilis }\end{array}$ & $\begin{array}{l}\text { Slopina purinų biosintezę ir limfoci- } \\
\text { tų proliferaciją }\end{array}$ & Leukocitopenija, viduriavimas \\
\hline & $\begin{array}{l}\text { Sirolimas/ } \\
\text { everolimas }\end{array}$ & $\begin{array}{l}\text { Sujungia FKBP-12; slopina citokinų } \\
\text { bei augimo faktoriaus proliferacini } \\
\text { poveiki }\end{array}$ & $\begin{array}{l}\text { Hiperlipemija, trombocitopenija, } \\
\text { artralgija }\end{array}$ \\
\hline
\end{tabular}

tyvëjusias, ir nesuaktyvejjusias. Brock ir kolegu [5] vykdytame 4 metu trukmès perspektyviajame tyrime, ị kuri buvo įtraukti 87 pacientai po plaučių transplantacijos, tiriamieji buvo išskirstyti ị tris indukcinès imunoterapijos grupes: pirmieji gavo OKT3, antrieji - ATG, o tretieji - daklizumabo. Per dvejus metus statistiškai reikšmingo skirtumo tarp grupių vertinant ūminių plaučių atmetimo

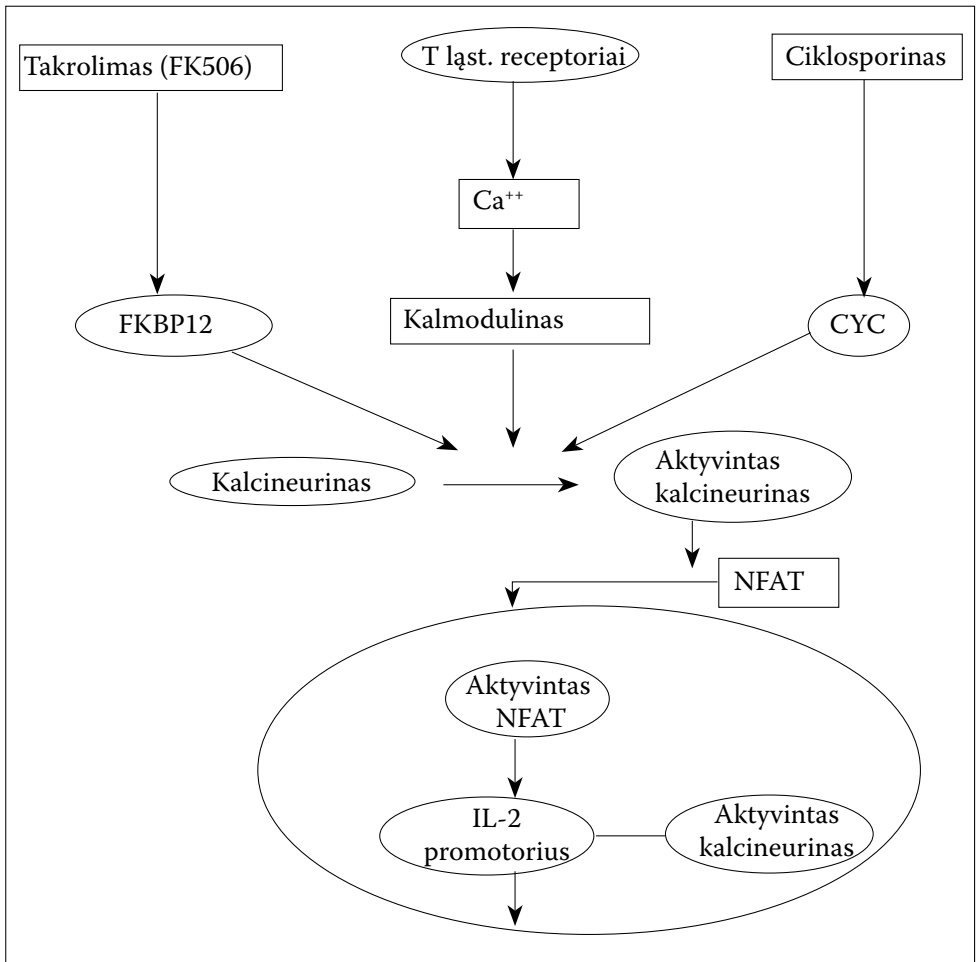

1 pav. IMUNOSUPRESINIŲ VAISTŲ VEIKIMO MECHANIZMAS reakciju dažnumą ir obliteracinio bronchiolito sindromo (OBS) pasireiškimą nebuvo. Pacientams, gavusiems OKT3, statistiškai reikšmingai dažniau nustatytos infekcijos (daugiausia bakterinės), šis skirtumas išryškëjo praejjus dviem mėnesiams po plaučių transplantacijos. Garrity su kolegomis [6] retrospektyviai lygino ūminių plaučių atmetimo reakcijų pasireiškimo dažnumą 27 pacientu grupejje, kuriems indukcinei imunosupresijai skirta daklizumabo, su 34 pacientu grupe, kurie gavo takrolimo, azatioprino, steroidų. Per šešių mėnesių laikotarpi ūminè atmetimo reakcija tiriamojoje grupèje pasireiškè 18 proc. pacientų, kontrolinèje grupejje 48 proc. Didesnio infekcijos dažnumo nenustatyta.

\section{PALAIKOMOJI IMUNOSUPRESIJA}

Palaikomosios imunosupresijos tikslas - apsaugoti nuo ūminès bei lètinès plaučiu atmetimo reakcijos. Palaikomajai imunosupresijai skiriami kalcineurino inhibitorius, antiproliferacinis vaistas ir gliukokortikosteroidas - trimis vaistais gydomi dauguma pacientu po plaučiuc transplantacijos [7]. Remiantis Tarptautinès širdies ir plaučių transplantacijos asociacijos 20042007 metų duomenimis, pagrindiniai palaikomosios imunosupresijos vaistų deriniai buvo šie: ciklosporinas A kartu su mikofenolato mofetiliu (41,5 proc.), ciklosporinas A su azatioprinu (59,3 proc.), takrolimas su mikofenolato mofetiliu (27,8 proc.), takrolimas su azatioprinu (30,5 proc.). Visi šie vaistai buvo vartojami kartu su steroidais.

Kalcineurino inhibitoriai. Ciklosporino A (CsA) imunosupresinès savybès nustatytos 1976 metais. CsA 
- ciklinis peptidas, išgaunamas iš grybo Tolypocladium inflatum. CsA, patekęs i ląstelę, jungiasi su citoplazmos baltymu ciklofilinu, tada CsA ir ciklofilino kompleksas jungiasi su kalcineurinu, slopina jo fosfatazès aktyvumą ir taip sumažina IL-2, $-3,-4,-5$, gama interferono, TNFalfa bei granulocitų/makrofagų kolonijas stimuliuojančių faktorių gamybą (1 pav.)

Takrolimas (Tac) - hidrofobinis makrociklinis laktonas, išskirtas iš aktinomiceto Streptomyces isukubaensis, 1984 metais. Ląsteliuc citoplazmoje Tac jungiasi su baltymu FKBP-12. Susidaręs kompleksas jungiasi su kalcineurinu ir toliau veikia labai panašiai kaip CsA. Tac in vitro yra 50-100 kartų aktyvesnè medžiaga nei CsA.

CsA ar Tac. CsA ir Tac efektyvumas po plaučiu transplantacijos lygintas tik keliais tyrimais. Keenan su kolegomis [42, 43] atliko atsitiktinių imčių tyrimą, kuriame dalyvavo 133 pacientai po plaučiu transplantacijos. Jie buvo gydomi arba CsA, arba Tac kartu su azatioprinu bei steroidais. Mažiau ūminių plaučių atmetimo reakcijų bei statistiškai reikšmingai mažiau OBS atvejų (38 proc., palyginti su 22 proc.) buvo nustatyta Tac grupèje. Pastebètas statistiškai nereikšmingas didesnis dviejų metų išgyvenamumas bei vẻlesnis OBS išsivystymas Tac grupėje $[8,9]$. Treede su kolegomis [10] vertino CsA bei Tac derini su mikofenotalo mofetiliu (2 g per dieną) bei steroidais. I atvirą perspektyvųji atsitiktinių imčių tyrimą įtraukta 50 pacientuc po plaučiu transplantacijos - indukcinei imunosupresijai jiems skirta ATG 3 dienas. Pastebèta, kad ūminių plaučių atmetimo reakcijų 6 ir 12 ménesių laikotarpiu buvo mažiau Tac grupejje, tačiau 12 mènesių išgyvenamumas buvo panašus.

Ląsteliuc ciklo inhibitoriai arba antiproliferaciniai vaistai. Azatioprinas (Aza) slopina DNR bei RNR sintezę ir taip mažina purinų biosintezę bei limfocitu proliferaciją, tačiau neveikia citokinų gamybos. Šiam vaistui būdingas ir uždegimą slopinantis poveikis.

Mikofenolato mofetilis (MMF) - tai provaistas, mikofenolinès rūgšties (MPA) esteris. Ši rūgštis išskirta iš Penicillinum sp. kultūrų. Vaisto veikimo principas panašus ì Aza. MMF gerai tirpsta mažo pH terpeje viršutiniame virškinamajame trakte ir yra greitai absorbuojamas. Kepenyse MMF greitai hidrolizuojamas i MPA bei neveiklųji metabolitą. Pastebėta, kad MPA koncentracija kraujyje būna mažesnè vartojant MMF kartu su CsA, o ne su Tac.

Aza ar MMF. Palmer su kolegomis [11] atliko daugiacentrị perspektyvųji atsitiktinių imčių tyrimą, ì kurị itrauktas 81 pacientas po plaučių transplantacijos. Pacientai gydyti CsA, steroidais bei Aza ( $2 \mathrm{mg} / \mathrm{kg}$ per dieną) arba MMF (2 g per dieną). Histologiškai patvirtintų ūminių atmetimo reakcijų ( $\geq$ A2) per 6 mènesius MMF grupejje (63 proc.) nustatyta daugiau nei Aza grupeje (58 proc.). CMV infekcijos dažnumas bei išgyvenamumas 6 ménesių laikotarpiu statistiškai reikšmingai nesiskyrè. Tyrejjai išvadose teigia, kad bendras ūminių atmetimo reakcijų dažnumas bei išgyvenamumas per 6 mènesius buvo panašūs abiejose pacientų grupèse. Tačiau trijų nedidelių neatsitiktinių imčių tyrimų duomenimis, vartojant MMF sumažejja histologiškai įrodytų ūminių atmetimo reakcijų epizodų skaičius ir/ar OBS dažnumas, ir/ar OBS pasideda vèliau [12, 13, 14].

Steroidai. Šiuo metu trijų vaistu palaikomoji imunosupresinè terapija po plaučiu transplantacijos vis dar tebèra būtina. Dauguma transplantacijos centru gydymą gliukokortikosteroidais pradeda ankstyvuoju pooperaciniu periodu: skiriama metilprednizolono it veną didelèmis dozèmis, vèliau pereinama prie geriamojo prednizolono. Jeigu indukcinei imunosupresijai skiriama ATG, tai metilprednizolono ị veną leidžiama tik keletą dienų, o geriamasis prednizolonas pradedamas vartoti tik prieš nutraukiant ATG, t. y. apytikriai 9-14 dieną po transplantacijos. Kol kas nèra atlikta tyrimų nustatyti, ar po plaučių transplantacijos galima slopinti imunitetą be steroiduc.

\section{ŪMINĖS ATMETIMO REAKCIJOS PO PLAUČIŲ TRANSPLANTACIJOS}

Atmetimo reakcijų dažnumas po plaučių transplantacijos yra kur kas didesnis nei po kitų organų. Per pirmuosius metus po plaučiu transplantacijos ūminè atmetimo reakcija pasireiškia nuo 27,8 iki 59,3 proc. atvejų, o po inkstu transplantacijos - nesiekia 17 proc. [15]. Paaiškinimų, kodèl ūminių atmetimo reakcijų po plaučių transplantacijos būna daugiau, gali būti keletas. Pirma, neimanoma atlikti perspektyviojo HLA suderinamumo testo. Antra, plaučių transplantatas, ne taip kaip visi kiti transplantuoti organai, nuolat sąveikauja su išorine aplinka ir taip nuolat veikiamas ịkvepiamų dūmų, toksinų, infekcinių veiksnių, kurie gali sukelti vietinị uždegimą ir paskatinti ūminę atmetimo reakciją. Trečia, plaučių transplantatas turi daug donoro ląstelių, išskiriančių antigenus, kurie nuolat gamina ir išskiria HLA aloantigenus recipiento limfocitams, pradedantiems imuninio atpažinimo procesą.

\section{Ūminių plaučių atmetimo reakcijų diagnostika bei klasifikacija}

Lengva ūminè atmetimo reakcija gali būti besimptomè. Pasireiškiantys simptomai parastai būna nespecifiniai: dusulys, subfebrili temperatūra, kosulys, hipoksemija ramybès ar fizinio krūvio metu.

Neinvaziniai ūminès plaučiu atmetimo reakcijos diagnostikos metodai. Forsuoto iškvepiamo tūrio per pirmąją sekundę $\left(\mathrm{FEV}_{1}\right)$ matavimo jautrumas ligoninèje diagnozuojant atmetimo reakciją svyruoja nuo 60 iki 75 proc. $[16,17]$. Tuo remiantis pacientai kasdien atlieka spirometrinius matavimus namuose naudodami nešiojamąji spirometrą. Ūminè plaučių atmetimo reakcija įtariama, jei spirometriniai rodmenys, registruoti namuose bei kiekvieno apsilankymo gydymo i̇staigoje metu, pablogèja: $\mathrm{FEV}_{1}$ sumažèja daugiau kaip 10 proc. (ar $\mathrm{FEF}_{25-75}-10-$ 15 proc.), palyginti su geriausiu asmeniniu dydžiu.

Atlikti du kryžminių grupių klinikiniai tyrimai, kuriais kaip ūminès plaučių atmetimo reakcijos žymuo vertintas iškvepiamas NO. Vieno tyrimo rezultatai paro- 
2 lentelè. HISTOLOGINĖ PLAUČIŲ ATMETIMO REAKCIJOS KLASIFIKACIJA

\begin{tabular}{|c|c|}
\hline $\begin{array}{l}\text { Plaučių atmetimo } \\
\text { reakcijos laispniai }\end{array}$ & Histologinis vaizdas \\
\hline A0 & Normali histologija (2 pav.) \\
\hline A1 (minimalus) & $\begin{array}{l}\text { Pavieniai negausūs perivaskuliniai mononu- } \\
\text { kleariniai infiltratai plaučių alveoliụ paren- } \\
\text { chimoje, kurie nèra akivaizdūs tiriant mažai } \\
\text { padidinus ( } 3 \text { pav.) }\end{array}$ \\
\hline A2 (lengvas) & $\begin{array}{l}\text { Gausūs perivaskuliniai mononukleariniai } \\
\text { infiltratai, apsupantys venules bei arterioles, } \\
\text { lengvai matomi mažai padidinus }\end{array}$ \\
\hline $\begin{array}{l}\text { A3 (vidutinio sun- } \\
\text { kumo) }\end{array}$ & $\begin{array}{l}\text { Tankūs perivaskuliniai mononukleariniai ir } \\
\text { uždegimo infiltratai, ịsiliejantys i perivaskuli- } \\
\text { nę bei perialveolinę pertvarą bei oro ertmes }\end{array}$ \\
\hline A4 (sunkus) & $\begin{array}{l}\text { Difuziniai perivaskuliniai ir intersticiniai bei } \\
\text { oro tarpu mononukleariniai infiltratai, žymus } \\
\text { alveoliocitu pažeidimas, susijęs su makrofa- } \\
\text { gais, hialininemis membranomis, hemoragi- } \\
\text { jomis bei neutrofilais }\end{array}$ \\
\hline Ax & Dèl bioptato nekokybiškumo nevertinama \\
\hline
\end{tabular}

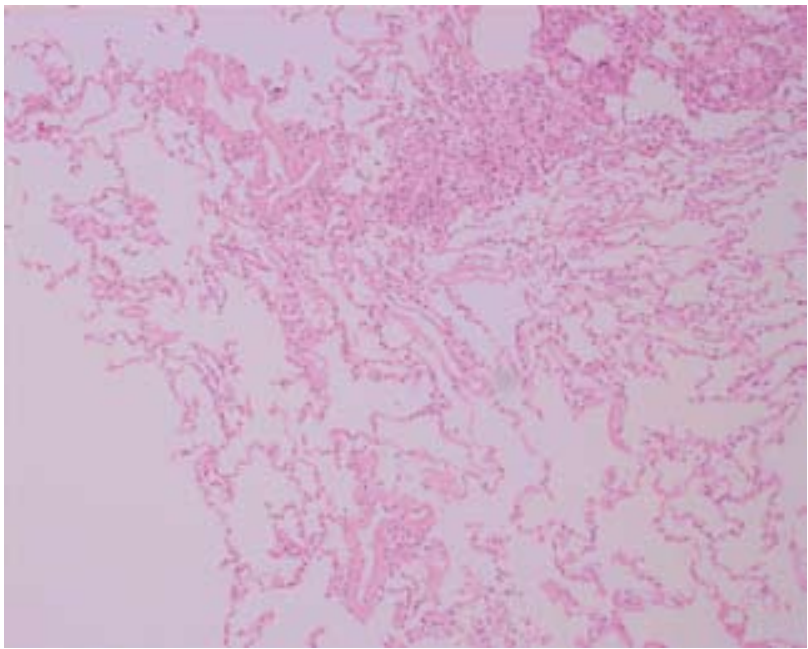

2 pav. ATMETIMO REAKCIJA AO - PLONASIENĖS ALVEOLÉS, MATYTI DVI NORMALIOS STRUKTÜROS KRAUJAGYSLĖS BE LIMBOCITINĖS REAKCIJOS SIENELĖSE

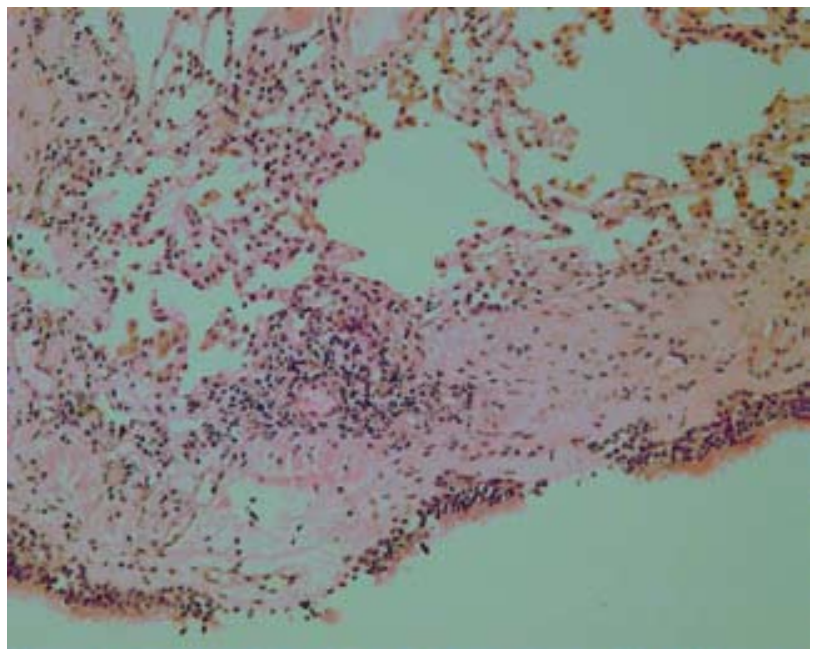

3 pav. ATMETIMO REAKCIJA A1 - PAVIENIAI MONOMORFONUKLEARINIAI INFILTRATAI ALVEOLIŲ PARENCHIMOJE

dè, kad iškvepiamo NO kiekis padidejja esant ūminiam kraujagysliniam atmetimui, kito - esant limfocitiniam
3 lentelè. KVĖPAVIMO TAKŲ UŽDEGIMO HISTOLOGINĖ KLASIFIKACIJA

\begin{tabular}{|c|c|}
\hline $\begin{array}{l}\text { Kvėpavimo takų } \\
\text { uždegimo laipsnis }\end{array}$ & Histologinis vaizdas \\
\hline B0 & Nėra kvėpavimo takų uždegimo \\
\hline B1 (minimalus) & $\begin{array}{l}\text { Retos pavienès mononuklearinès ląstelès bron- } \\
\text { chų ar bronchiolių pogleivyje }\end{array}$ \\
\hline B2 (lengvas) & $\begin{array}{l}\text { Apskritimo formos mononuklearinių ląstelių } \\
\text { sankaupos su pavieniais eozinofilais bronchų ar } \\
\text { bronchiolių pogleivyje, nèra epitelio nekrozės ar } \\
\text { invazijos į epiteli }\end{array}$ \\
\hline $\begin{array}{l}\text { B3 (vidutinio sun- } \\
\text { kumo) }\end{array}$ & $\begin{array}{l}\text { Tankios apskritimo formos mononuklearinių } \\
\text { ląstelių sankaupos bronchų ar bronchiolių po- } \\
\text { gleivyje, limfocituc ir eozinofiluc migracija per } \\
\text { epitelį, epiteliocitų apoptozė }\end{array}$ \\
\hline B4 (sunkus) & $\begin{array}{l}\text { Apskritimo formos mononuklearinių ląstelių san- } \\
\text { kaupos bronchųar bronchiolių pogleivyje, susijusios } \\
\text { su epitelio atsiskyrimo nuo pamatinès membranos, } \\
\text { epitelio išopèjimu, epitelinių ląstelių nekroze, fibro- } \\
\text { pūlingu eksudatu bronchiolių spindžiuose }\end{array}$ \\
\hline $\mathrm{Bx}$ & Dèl bioptato nekokybiškumo nevertinama \\
\hline
\end{tabular}

alveolitui $[19,20]$. Tačiau šis metodas nèra plačiau taikomas atmetimo reakcijoms nustatyti.

Krūtinès ląstos rentgenogramoje gali būti matoma aiški, židininė alveolių ar intersticinè infiltracija, pleurito požymių. Pokyčius kartais sunku atskirti nuo pneumonijos.

Klinikinių požymių (dusulio, subfebrilaus karščiavimo, kosulio) bei neinvazinių tyrimų (plaučių funkcijos ivvertinimo, krūtinès ląstos rentgenogramos) duomenų atskirti plaučių infekciją nuo plaučių atmetimo reakcijos nepakanka.

Invaziniai ūminès plaučių atmetimo reakcijos diagnostikos metodai. Auksinis standartas plaučių transplantato atmetimo reakcijoms nustatyti tebèra plaučių audinio biopsija ir bronchų bei alveolių nuoplovu (BAL) histologinis tyrimas. Ūminès plaučiu atmetimo reakcijos klasifikuojamos pagal Tarptautinę širdies ir plaučių transplantacijos asociacijos pateiktą klasifikaciją ( 2 ir 3 lentelès). Kad būtų nustatyta, ar yra ūminè plaučiu atmetimo reakcija, vertinami du kriterijai. Pagrindinis ūminès plaučiu atmetimo reakcijos vertinimo kriterijus - mononuklearinè infiltracija apie periferiniame plaučiuc audinyje esančias smulkiąsias kraujagysles (A0-A4). Kaip svarbus veiksnys vystytis lètinei atmetimo reakcijai, papildomai vertinami uždegimo sukeliami pokyčiai (B0-B4) smulkiuosiuose kvèpavimo takuose (bronchuose, bronchiolèse). Biopsijos rezultatai turi būti vertinami gydytojo patologo, turinčio patirties vertinti plaučius po transplantacijos.

Tarptautinès širdies ir plaučių transplantacijos asociacijos duomenimis, 66 proc. centru atlieka transbronchines biopsijas (TBB) pagal protokolą tam tikrais intervalais per pirmuosius dvejus metus (kas 3 mèn., vẻliau kas 6 mèn.) po transplantacijos, tačiau kiti centrai TBB atlieka tik tada, kai atsiranda nauju simptomu ar požymių [21]. Tyrimai rodo, kad TBB, atliekamos pagal protokolą pacientams, kuriems nèra simptomų, ūminę atmetimo reakciją gali parodyti nuo $22-73$ proc. atvejų [22, 23]. Pažymètina, kad perspektyviųjų tyrimų, 
skirtų įvertinti stebimųju TBB įtaką OBS atsiradimui ar išgyvenamumui, neatlikta. Kai kurie centrai pateikia duomenis, paremiančius nuomonę, kad klinikiniai rezultatai geri ir nekartojant TBB [24].

\section{Ūminès ir lètinès plaučių atmetimo reakcijos ryšys}

Ūminė plaučių atmetimo reakcija nesukelia mirties, išskyrus keletą užfiksuotų pavienių atvejų. Tačiau ūminès atmetimo reakcijos (ypač labai ryškios kliniškai, pasikartojančios ir/ar vèlyvosios) laikomos pagrindiniu rizikos veiksniu obliteraciniam bronchiolitui (OB) ar obliteracinio bronchiolito sindromui prasidèti [25]. Kol kas ryšys tarp ūminių atmetimo reakcijų bei OBS vystymosi neaiškus. Kai kuriais atvejais OBS pasireiškia ir toliau progresuoja tuoj po ūminès plaučiu atmetimo reakcijos, kitais - po atmetimo reakcijos ir sėkmingo jos gydymo praeina daug laiko, kol pasireiškia OBS. Galiausiai yra pacientu, kuriems OBS prasideda, nors nebuvo diagnozuota nè vieno ūminès plaučiu atmetimo reakcijos epizodo [26-28]. Bet kokiu atveju veiksminga ūminių plaučiu atmetimo reakciju profilaktika turi būti pagrindinis imunosupresinio gydymo po plaučiu transplantacijos tikslas.

\section{Ūminių plaučių atmetimo reakcijų gydymas}

Nekomplikuotai ūminei atmetimo reakcijai gydyti dažniausiai skiriama metilprednizolono it veną pulsiniu režimu keletą dienų, vèliau pereinama prie geriamojo prednizolono.

Gydant persistuojančią ar pasikartojančią ūminę plaučių atmetimo reakciją, svarbiausia ciklosporiną A pakeisti takrolimu. Tac buvo sèkmingai gydomos sunkiai paveikiamos ūminès bei lètinès atmetimo reakcijos po inkstu [29], kepenu [30] bei širdies [31] transplantavimo.

Po plaučių transplantacijos persistuojančių bei pasikartojančių ūminių atmetimo reakcijų gydymo efektyvumas pakeitus CsA i Tac vertintas keliais nedideliais tyrimais. Griffith ir kolegu [32] tyrime dalyvavo 13 pacientų: pasikartojanti ūminè plaučių atmetimo reakcija išgydyta aštuoniems pacientams, o dviem nustatytas ženklus pagerèjimas. Horning su kolegomis [33] tyrè 14 pacientų. CsA pakeitus Tac, gerokai sumažejo plaučiu atmetimo reakcijų epizodų vertinant histologini atmetimo laipsni. Onsager ir kolegu [34] tyrimo duomenimis, histologiškai patvirtinta, kad ūminè plaučių atmetimo reakcija praejjo aštuoniems pacientams, o trims pacientams stabilizavosi FEV1, tačiau keturiems pacientams gydymas Tac vietoj CsA nebuvo veiksmingas. Tarptautiniu retrospektyviuoju tyrimu (dar nepublikuota) vertinti 110 pacientų, kuriems diagnozuota persistuojanti/pasikartojanti ūminè plaučių atmetimo reakcija, duomenys. Nustatyta, kad, CsA pakeitus ì Tac, smarkiai sumažèjo ūminių plaučių atmetimo reakcijų skaičius (diagnozuota histologiškai ar kliniškai) bei protarpinio gydymo steroidais dažnumas. Net 94 proc. pacientų sumažèjo ūminès plaučių atmetimo reakcijos epizodų, o ūminè atmetimo reakcija ciklosporiną $\mathrm{A}$ pakeitus takrolimu buvo nustatyta tik 22 proc. pacientų.

Jau yra naujų tyrimų duomenų, rodančių, kad Tac stabdo OBS progresavimą netgi gydant pažengusią ligą
[35]. Taigi šiuo metu ciklosporino pakeitimas takrolimu yra pirmasis žingsnis gydant atsparią, persistuojančią ūminę atmetimo reakciją [36]. Antras žingsnis monokloniniu (baziliksimabas) ar polikloninių antilimfocitų antikūnų (ATG) pridèjimas.

Papildomos gydymo galimybès: metotreksatas [37], aerozolinès steroidu [38] ar ciklosporino formos [39], fotoferezè [40], limfmazgių švitinimas [41], didelių dozių (2 $\mathrm{g} / \mathrm{kg}$ ) intraveninių imunoglobulinų infuzija. Pastarojo metodo efektyvumas buvo įrodytas gydant ūmines atmetimo reakcijas po inkstų bei širdies transplantacijų [42].

\section{LÉTINIŲ PLAUČIŲ ATMETIMO REAKCIJŲ DIAGNOSTIKA BEI KLASIFIKACIJA}

Lètinè plaučių atmetimo reakcija - pagrindinė mirties po plaučių transplantacijos priežastis. Obliteracinis bronchiolitas - tai patologinis procesas, pažeidžiantis smulkiuosius kvèpavimo takus, kai limfocitai prasiskverbia pro pamatinę membraną i̇ epitelị ir taip sukelia epitelinių ląstelių nekrozę. Atsipalaidavę citokinai bei kiti uždegimo mediatoriai veikia neutrofilus, kurie stimuliuoja fibroblastų migraciją. Tai sąlygoja granuliacinio audinio formavimąsi bei, tikètina, smulkiụjų kvẻpavimo takų spindžio randejjimą [43]. Lètinio atmetimo diagnozè transbronchine biopsija yra sunkiai nustatoma (20 proc.). Paprastai OB diagnozuojamas padarius atvirą plaučiu biopsiją, eksplantaciją ar retransplantaciją arba net autopsijos metu. Tarptautinè širdies ir plaučių transplantacijos asociacija suformulavo klasifikacijos sistemą, apibūdinančią klinikini sindromą, kuris pasireiškia esant histologiškai patvirtintam OB [44]. OBS pagrindžiamas klinikinių, radiologinių bei plaučių funkcijos mèginių deriniu. OBS stadija nustatoma pagal $\mathrm{FEV}_{1}$ ar $\mathrm{FEF}_{25-75}$ sumažéjimą procentais, palyginti su geriausiais asmeniniais potransplantaciniais duomenimis (4 lentelè).

Norint diagnozuoti OBS, reikia atmesti kitas ligas (infekciją, ūminę atmetimo reakciją, anastomozinę striktūrą, bronchomaliaciją, progresuojančią igimtą plaučių ligą) ir būtina atlikti bronchoskopiją su transbronchine biopsija.

Lètinių plaučių atmetimo reakcijų gydymas susideda iš kelių veiksmų: 1) modifikuojama palaikomoji imunosupresija; 2) rekomenduojama pridèti inhaliuojamųjų imunosupresiniu vaistų (bet Lietuvoje jie neregistruoti); 3) imunosupresinis gydymas papildomas

4 lentelè. OBLITERACINIO BRONCHIOLITO SINDROMO KLINIKINÉS STADIJOS

\begin{tabular}{lll}
\hline Stadija & Apibūdinimas & $\begin{array}{l}\mathrm{FEV}_{1} \\
(\text { proc. geriausio asmeninio dydžio) }\end{array}$ \\
\hline OBS 0 & Nėra OB & $>90\left(\mathrm{FEF}_{25-75}>75\right)$ \\
\hline OBS 0p & Galimas OB & $81-90\left(\mathrm{ir} / \mathrm{arEF}_{25-75}<75\right)$ \\
\hline OBS 1 & Lengvas OB & $66-80$ \\
\hline OBS 2 & $\begin{array}{l}\text { Vidutinio } \\
\text { sunkumo OB }\end{array}$ & $51-65$ \\
\hline OBS 3 & Sunkus OB & $<50$ \\
\hline
\end{tabular}


kitu grupiu vaistais (ATG, ciklofosfamidu, metotreksatu); 4) taikomas imuninę sistemą moduliuojantis gydymas (limfmazgių švitinimas, fotoferezè).

Palaikomosios imunosupresijos modifikavimas. Visu pirma rekomenduojama CsA pakeisti i Tac. Keliais nedideliais tyrimais vertintas CsA pakeitimo i Tac veiksmingumas gydant pacientus, kuriems diagnozuotas OBS [45-48]. Visu tyrimų rezultatai rodo, kad vietoj CsA vartojamas Tac statistiškai reikšmingai sumažino FEV1 blogejjimą bei stabilizavo ši rodiklị.

Dar rekomenduojama azatiopriną pakeisti mikofenolato mofetiliu. Keletas centru írodè, jog pakeitus Aza ị MMF pacientams, kuriems yra OBS, stabilizavosi plaučių funkcijos rodikliai $[49,50]$.

Inhaliuojamuju imunosupresiniu vaistu pridejjimas. Manoma, jog, gydant lètinę atmetimo reakciją inhaliuojamaisiais imunosupresantais, susidaro didesnè vaisto koncentracija būtent patologineje vietoje (t. y. apatiniuose kvèpavimo takuose) bei išvengiama sisteminio vaistu poveikio. Tuo remdamiesi Lacono su kolegomis [51] atliko tyrimą, kuriame septyniems iš devynių pacientų, patyrusių lètinę atmetimo reakciją, gydant inhaliuojamuoju CsA stabilizuota plaučiu funkcija. Tačiau šiuo metu inhaliuojamasis CsA toliau tiriamas ir kol kas nèra vartojamas klinikineje praktikoje.

Imunosupresinio gydymo papildymas. Pirmą kartą diagnozavus OBS, dažniausiai skiriama metilprednizolono pulsiniu režimu, nors šis gydymo būdas yra empirinis ir nebuvo moksliškai įrodytas. Jei nèra klinikinio atsako ị dideles gliukokortikosteroidų dozes, dažnu atveju pridedama antilimfocitinio globulino (ATG) arba IL-2 receptoriu antagonisto (baziliksimabo, daklizumabo). Trijų retrospektyviųjų tyrimų duomenimis, paskyrus ATG pacientams, sergantiems OBS, stabilizuojama plaučių funkcija ar pristabdomas plaučių funkcijos blogèjimas 3-12 mènesių laikotarpiu [52-54].

Vienu retrospektyviuoju tyrimu vertintas iprastinès imunosupresinès terapijos kartu su metotreksatu poveikis 10 pacientų, sergančių progresuojančiu OBS. Klinikinis atsakas nustatytas aštuoniems pacientams: dviem pastebètas klinikinis pagerejimas, penkiems stabilizavosi plaučiu funkcija (per 6 stebejjimo mènesius), vieno paciento būklè pablogejjo [55] Gydymas ciklofosfamidu vertintas tiriant septynis pacientus, kuriems buvo lètinė plaučiuc atmetimo reakcija. Šešiems pacientams stabilizavosi ar padidejo FEV1 [56]. Kol kas nuomonès apie gydymą metotreksatu bei ciklofosfamidu prieštaringos, kadangi nèra atlikta didelių tyrimų, be to, šių vaistu toksiškumas labai didelis.

Imunomoduliuojamasis gydymas. Paraaortiniu limfmazgių apšvitinimas sumine 8 Gy doze. Habib su kolegomis [57] retrospektyviai palygino 26 pacientams, sergantiems 2 ar 3 stadijos OBS, taikytas dvi gydymo taktikas. Vieniems jų CsA pakeistas Tac, kitiems - švitinti limfmazgiai. Abiejų gydymo būdų veiksmingumas buvo vienodas, tačiau Tac grupejje pastebèta mažesnè infekciju rizika bei mirtingumas. Tuo remiantis, siūloma visu pirma CsA pakeisti takrolimu, o tik vẻliau taikyti limfmazgių apšvitinimą.

Fotoferezè - tai leukoferezès pagrindu grịstas imunomoduliuojamasis gydymas, kai limfocitai, paveikti 8-metoksipsoraleno (8-MOP), apšvitinti UVA spin- duliais, grąžinami i paciento kraujotaką. O’Hagan su kolegomis [58] paskelbė 5 pacientų, kurie buvo gydomi fotofereze nuo OBS, duomenis. Visų penkių būklè pagerèjo bei stabilizavosi plaučiu funkcija, tačiau vienas pacientas mirè nuo oportunistinès infekcijos.

Slovis su kolegomis [59] tyrė tris OBS sergančius pacientus, kuriems plaučių funkcija blogejjo, iprastinè imunosupresija poveikio nedare bei nebuvo atsako it ATG, jie gydyti fotofereze. Vienam pacientui nustatytas plaučių funkcijos pagerèjimas, dviem - simptomų stabilizavimasis. Būtina paminèti, kad fotoferezè nesukelia jokio ženklesnio šalutinio poveikio.

\section{IMMUNOSUPPRESSIVE THERAPY AFTER LUNG TRANSPLANTATION}

\section{EDITA GASIŪNIENÉ ', VALDAS ŠARAUSKAS ², BRIGITA ŠITKAUSKIENÉ 'DEPARTMENT OF PULMONOLOGY AND IMMUNOLOGY 2DEPARTMENT OF PATHOLOGICAL ANATOMY KAUNAS UNIVERSITY OF MEDICINE}

Key words: induction immunosuppressive therapy, maintenance immunosuppressive therapy, rejection, lung transplantation.

Summary. Data from the Registry of the International Society for Heart and Lung Transplantation (ISHLT) indicated that in 2000-2006 54 proc. patients after lung transplantation received induction therapy. with antilymphocyte antibodies, monoclonal antibody or anti-interleukin-2-receptor monoclonal antibodies. The vast majority of lung transplant recipients receive a triple-drug maintenance regimen including a calcineurin inhibitor, a cell-cycle inhibitor and steroids. Shift from cyclosporin A to tacrolimus has emerged as the first treatment step of refractory acute rejection followed by high-dose steroids or antilymphocyte agents, total lymphoid irradiation or photopheresis. The treatment of chronic rejection remains deceptive and includes varied strategies such as modification of the maintenance regimen, augmentation of the immunosuppression and/or total lymphoid irradiation and photopheresis.

\section{LITERATŨRA}

1. Abramowicz D, Wissing $\mathrm{KM}$, Broeders $\mathrm{N}$. Induction therapy with antiCD3 antibodies. Curr Opin Organ Transplant1999; 4: 312-317.

2. Bourdage JS, Hamlin DM. Comparative polyclonal antithymocyte globulin and antilymphocyte/anti-lymphoblast globulin anti-CD antigen analysis by flow cytometry. Transplantation 1995; 59: 1194-1200.

3. Abouna GM, al-Abdullah IH, Kelly Sullivan D, et al. Randomized clinical trial of antithymocyte globulin induction in renal transplantation comparing a fixed daily dose with dose adjustment according to $T$ cell monitoring. Transplantation 1995; 59: 1564-1568.

4. Djamali A, Turc-Baron C, Portales P, et al. Low dose antithymocyte globulins in renal transplantation: daily versus intermittent administration based on T-cell monitoring. Transplantation 2000; 69: 799-805.

5. Brock MV, Borja MC, Ferber L, et al. Induction therapy in lung transplantation: a prospective, controlled clinical trial comparing OKT3, antithymocyte globulin, and daclizumab. J Heart Lung Transplant 2001; 20 1282-1290.

6. Garrity ER, Villanueva J, Bhorade SM, Husain AN, Vigneswaran WT. Low rate of acute lung allograft rejection after the use of daclizumab, an interleukin 2 receptor antibody. Transplantation 2001; 71: 773-777.

7. Glanville AR, Corris PA, McNeil KD, Wahlers T. Mycophenolate mofetil vs. azathioprine in lung transplantation for the prevention of bronchiolitis obliterans syndrome: results of a 3-year international randomised trial. Heart Lung Transplant 2003; 22: Suppl. 1, S207.

8. Keenan RJ, Konishi H, Kawai A, et al. Clinical trial of tacrolimus versus cyclosporine in lung transplantation. Ann Thorac Surg 1995; 60: 580-585.

9. Keenan RJ, Dauber JH, lacono AT, Zaldonis D, Griffith BP. Long-term followup clinical trial of tacrolimus versus

cyclosporine for lung transplantation. J Heart Lung Transplant 1998; 17: 61

10. Treede $\mathrm{H}$, Klepetko W, Reichenspurner $\mathrm{H}$, et al. Tacrolimus versus cyclosporine after lung transplantation: a prospective, open, randomized two-center trial comparing two different immunosuppressive protocols. J Heart Lung Transplant 2001; 20: 511-517.

Kiti literatūros šaltiniai - redakcijoje (iš viso 61). 